\title{
ANALISIS USAHA PEMBIAKAN SAPI POTONG POLA KEMITRAAN ANTARA KORPORASI DENGAN PETERNAK RAKYAT
}

\author{
Rochadi Tawaf \\ Fakultas Peternakan Universitas Padjadajaran \\ E-mail: rochadi@unpad.ac.id
}

\begin{abstract}
ABSTRAK. Kebijakan Permentan nomor 2/2017 tentang rasio importasi sapi bakalan dan indukan, mengharuskan perusahaan penggemukan melakukan usaha pembiakan serta bermitra dengan peternakan rakyat. Sejauhmana kebijakan ini dapat direalisasikan perlu kajian usaha pembiakan dan penggemukan merupakan dua usaha yang sangat berbeda. Tujuan Penelitian ini adalah untuk mengetahui apakah usaha pembiakan sapi potong dengan pola kemitraan antara korporasi dengan peternakn rakyat dapat dilaksanakan sesuai dengan kebijakan pemerintah. Penelitian ini dilaksanakan dengan metode survey pada tiga korporasi penggemukan sapi potong yang bermitra dengan peternak rakyat di provinsi Kalimantan Tengah, Banten dan Provinsi Lampung. Data yang terkumpul dianalisis secara deskriptif dan finansial. Hasil penelitian menunjukan bahwa : (1) Usaha pembiakan sapi potong secara intensif tingkat keuntungannya negative. (2) Agar usaha pembiakan dapat berjalan dengan baik pada pola usaha intensif, maka diperlukan kontribusi perusahaan feedlot terhadap biaya pakan sebesar Rp 400,00/kg. Selain itu,diperlukan fasilitas bunga bank 5\% per tahun dengan tenggang waktu pembayaran hutang 18 bulan. (3) Dari tiga pola kemitraan yang dianalisis, direkomendasikan pola kemitraan tahap pertama dan ketiga dengan skala usaha 100 ekor per kelompok.
\end{abstract}

Kata kunci: pembiakan, penggemukan, kemitraan, perusahaan, peternak rakyat

\section{CATTLE BREEDING FARM ANALYSIS OF PARTNERSHIP BETWEEN CORPORATION WITH SMALLHOLDER}

\begin{abstract}
The minister of agriculture decree number 2/2017 on the ratio of imported feeder and female cattle fattening enterprises to conducted breeding farm as well as partnering with the smallholder farms. whether this policy could be realized, it is require a critical study because the business of breeding and fattening are two kind different farm activities. The purpose of this study is to determine whether the cattle breeding partnersip could be implemented in accordance with government policy.This research was conducted by survey method on three corporation of beef cattle fattening which partnered with smallholder farmers in Central Kalimantan Province, Banten Province and Lampung Province.The data were analyzed by descriptively and financially. The results showed that:(1) Breeding beef cattle intensively results in a negative provitability (2) In order for the breeding farm to running well on the pattern of intensive, it is necessary contribution of feedlot company to feed cost of IDR 400.00/kg. In addition, the government should be able to contribute with a 5\% bank interest facility per year with a grace period of 18 months debt payment. (3) Of the three modeled breeding partnerships analyzed, the first and third stage partnership model can be recommended to be realized with the scale of business per group of 100 heads.
\end{abstract}

Key words: breeding, fattening, partnership, corporation and smallholder farm

\section{PENDAHULUAN}

Pada tanggal 20 Oktober 2016 telah diundangkan Peraturan Menteri Pertanian (Permentan) Nomor 49/ Permentan/Pk440/10/2016 tentang Pemasukan Ternak Ruminansia Besar ke dalam Wilayah Negara Republik Indonesia, menggantikan Permentan nomor. 16/Permentan/Pk.440/5/2016) dengan maksud untuk memenuhi ketersediaan daging sapi, mempercepat peningkatan populasi, dan mengoptimalkan pelayanan pemberian rekomendasi pemasukan ternak ruminansia besar. Dalam hal ini yang menjadi fokus perhatian adalah ketentuan harus adanya rasio jumlah indukan dan bakalan impor yang dimasukkan minimal (1:5) untuk pelaku usaha penggemukan, dan (1:10) untuk koperasi peternak dan kelompok peternak.

Dalam rangka penyempurnaan kebijakan rasio impor antara sapi indukan dengan sapi bakalan, pemerintah telah mengeluarkan kebijakan, yaitu Permentan No. 02/Permentan/Pk.440/2/2017 tentang perubahan atas Permentan No. 49/2016. Ditambahkan bahwa audit pertama kali akan dilakukan pada bulan Desember 2018, dan audit selanjutnya dilakukan setiap dua tahun sekali. Perubahan lainnya adalah tentang spesifikasi bakalan dari maksimal rataan $350 \mathrm{~kg}$ (untuk sapi) dan $400 \mathrm{~kg}$ (untuk kerbau), menjadi maksimal rataan $450 \mathrm{~kg}$ untuk sapi dan kerbau, dengan kewajiban digemukkan paling cepat empat bulan setelah selesai karantina.

Seperti diketahui bahwa usaha penggemukan sapi sangat berbeda dengan usaha pembiakan. Usaha pembiakan sapi secara komersial umumnya dilakukan oleh peternak yang memiliki modal besar serta menerapkan teknologi modern (Mubyarto dalam Anggraini 2003). Menurut Nasoetion dalam Winarso dkk. (2005) bahwa dalam upaya pengembangan sapi potong, pemerintah menempuh dua kebijakan, yaitu 
ekstensifikasi dan intensifikasi. Pengembangan secara ekstensifikasi menitik beratkan pada peningkatan populasi yang didukung oleh pengadaan dan peningkatan mutu bibit, penanggulangan penyakit, penyuluhan dan pembinaan usaha, bantuan perkreditan, pengadaan dan peningkatan mutu pakan,dan pemasaran.

Usaha peternakan memerlukan modal besar, terutama untuk pengadaan pakan dan bibit. Biaya yang besar ini sulit dipenuhi oleh peternak rakyat yang pada umumnya memiliki keterbatasan modal (Hadi dan Ilham 2000). Usaha penggemukan dilakukan dalam jangka waktu empat bulan/periode, sedangkan usaha pembiakan dilakukan dalam waktu yang cukup panjang (5-7 tahun/ periode). Hal ini, sesuai dengan penjelasan UU No. 18/2009 jo. 41/2014 tentang PKH bahwa sapi betina produktif adalah sapi yang telah melahirkan kurang dari 5 kali atau umur dibawah 8 tahun. Pola produksi ini berpengaruh pada cash flow usaha, dimana usaha penggemukan lebih cepat perputarannya dibanding dengan usaha pembiakan yang membutuhkan jangka waktu relatif panjang untuk memperoleh keuntungan. Integrasi ternak dapat dilakukan melalui pola kemitraan antara pihak perusahaan dan petani-ternak atau pemerintah daerah (Suharto 2004).

Berdasarkan hasil simulasi terhadap dinamika Populasi yang disesuaikan dengan kebijakan Permentan No. 02/2017 Jo. 49/2016, bahwa usaha penggemukan dengan kapasitas kandang 10.000 ekor, dalam kondisi normal akan mampu melakukan importasi sapi bakalan sebanyak 30.000 ekor dan sapi indukan sebanyak 6.000 ekor dalam setahun. Apabila kapasitas kandang yang dimiliki tidak bertambah, maka pada tahun 2018 importasi sapi bakalan penggemukan harus dikurangi akibat jumlah sapi indukan yang dipelihara akan terakumulasi menjadi 11.100 ekor. Hal ini berkaitan dengan pemberlakuan permentan No. 02/2017 jo. No. 49/ 2016 terhitung sejak importasi feedlot pada awal tahun 2017, sehingga pemenuhan realisasi impor sapi indukan pada tahun 2018 akan dilakukan dua kali lipat, karena terhutang kewajiban pada tahun 2017 yang belum dilakukan (Agus dkk, 2017).

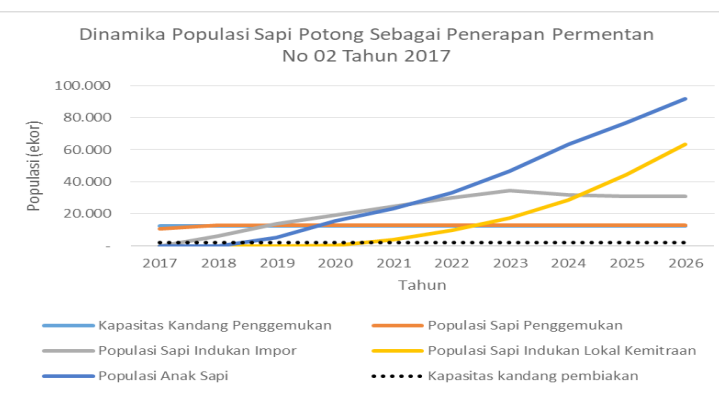

Gambar 1. Perspektif Dinamika Populasi Sapi Potong berdasarkan Permentan No. 02/2017 (Agus dkk, 2017)

Hasil perhitungan tersebut, menunjukan bahwa pada tahun 2019 bulan ke 2 populasi indukan impor yang dipelihara sudah melebihi jumlah populasi sapi penggemukan.Hal ini, menyebabkan fasilitas kandang yang ada, tidak dapat menampung sapi penggemukan dalam arti feedloter tidak dapat melakukan kegiatan usaha penggemukannya. Dalam hal ini jumlah sapi indukan impor dan keturunannya memerlukan luasan kandang sekitar tiga kali lipat dari usaha penggemukan. Sementara itu, para pengusaha memiliki keterbatasan dalam kepemilikan kandang/lahan, dengan kata lain kandang dan lahannya tidak bertambah.

Kondisi faktual yang terjadi, sampai saat ini hanya beberapa pengusaha penggemukan sapi yang melakukan impor sapi indukan sesuai dengan Permentan No 2/2017. Hal ini disebabkan, perusahaan penggemukan tersebut telah lama menjalankan pola kemitraan dengan peternakan rakyat. Pola kemitraan yang telah dilakukan ada tiga jenis yaitu, kemitraan yang hasil produksinya (1) pedet, (2) sapi bakalan dan (3) sapi siap potong. Kemitraan seperti ini perlu terus disebarluaskan mengingat bahwa ketergantungan Indonesia terhadap daging sapi impor akan meningkat, dan kebutuhan konsumsi dalam negeri akan terus dipasok oleh daging impor (Handayani dkk, 2016).

Berdasarkan fenomena yang terjadi, diperoleh informasi sebagai berikut: (1) bahwa kewajiban impor sapi indukan berbasis pada jumlah impor sapi bakalan. Hal ini menyebabkan jumlah sapi indukan yang dipelihara akan lebih banyak dari pada jumlah sapi bakalan yang dipelihara. (2) bahwa tidak tersedianya lahan dan kandang yang cukup dimiliki perusahaan feedlot untuk pengembangan sapi indukan.

Berdasar atas kondisi tersebut, perlu dilakukan kemitraan usaha antara perusahaan penggemukan dengan peternak rakyat sebagai plasma. Penelitian ini ditujukan untuk memperoleh gambaran mengenai analisis kondisi usaha kemitraan antara peternak rakyat dengan perusahaan.

\section{METODE}

Metode penelitian yang digunakan adalah survey pada tiga perusahaan feedlotpada tanggal 1 September 2017 sampai dengan 30 Nopember 2017. Data primer diperoleh dari perusahaan feedlot sedangkan data sekunder berasal dari:

a. Badan Pusat Statistik, Ditjen Peternakan dan Kesehatan Hewan, Dinas peternakan Provinsi mengenai: populasi ternak, data peternak, data produksi daging, data impor sapi dan daging.

b. Studi Kepustakaan yang berkaitan dengan kajian ini.

c. Peraturan Perundang-undangan, Peraturan Presiden, Peraturan Menteri ataupun Peraturan lain yang setara atau di bawahnya yang terkit dengan penelitian.

Korporasi adalah perusahaan feedlot yang ditetapkan sebagai responden untuk mencari data primer yang terkait kajian ini. Metode yang digunakan untuk 
penentuan sampel adalah purposif sampling berdasarkan kepada perusahaan feedlot yang melakukan kemitraan dengan peternak rakyat, yaitu : PT A di Banten, PT B di Lampung dan PT. C di Kalimantan Tengah.

Pengambilan data primer dilakukan dengan teknik wawancara. Pertanyaan yang diajukan oleh peneliti dalam bentuk pertanyaan tertutup dan terbuka yang sudah dipersiapkan terlebih dahulu. Data yang terkumpul dilakukan simulasi secara deskriptif dan analisis finansial usaha ternak pada usaha kelompok peternak sapi potong.

Simulasi pola kemitraan antara perusahaan feedlot dengan peternakan rakyat, dilakukan sesuai dengan hasil kajian Fapet UGM (2017), lihat Gambar. 1.

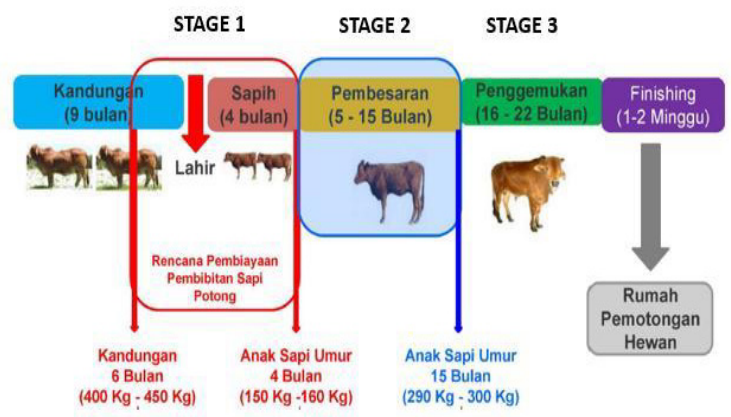

Gambar 1. Tiga Tahapan kemitraan Usaha Pembiakan sapi Potong (sumber : Agus dkk, 2017.)

Berdasarkan pada Gambar 1, rincian kegiatan ke tiga pola kemitraan sebagai berikut :

1. Pola Kemitraan Pemeliharaan Tahap-1: kemitraan dilakukan antara perusahaan feedlot dengan peternakan rakyat sebagai peternak mitra. Dimana sapi dara bunting diperoleh dari perusahaan feedlot, yang dipelihara oleh peternak rakyat dengan pembinaan teknologi dan pasar oleh perusahaan feedlot. Pada analisis tahapan ini, peternak rakyat menjual hasil produksinya berupa sapi pedet lepas sapih dan indukannya.

2. Pola KemitraanPemeliharaan Tahap-2: yaitu peternak rakyat sebagai peternak mitra, memelihara sejak sapi dara bunting yang diperoleh dari perusahaan feedlotsampai dengan anakan yang dihasilkan dipelihara sebagai sapi bakalan. Hasil produksi dari pemeliharaan pada tahap ini adalah sapi bakalan dan indukan. Perlakuannya mulai dari pemeliharaan indukan bunting sampai melahirkan anak (pedet), kemudian pemeliharaan Induk dan anak menyusui, penyapihan pedet untuk kemudian melakukan pembesaran (rearing) sampai menjadi sapi bakalan (jantan) dan atau dara/calon induk (betina) pada umur 18 bulan.

3. Pola kemitraan Pemeliharaan Tahap-3: yaitu peternak rakyat sebagai peternak mitra, memelihara sapi sejak sapi dara bunting yang diperoleh dari perusahaan feedlot sampai dengan melakukan penggemukkan pada skala peternakan rakyat. Hasil produksi dari tahapan ini adalah berupa sapi siap potong.

Peternakan rakyat sebagai kelompok peternak mitra, berskala usaha dibawah 100 ekor per kelompok kluster, hal ini sesuai dengan peraturan yang berlaku. Kelompok ini, berskala usaha antara 5-10 ekor per peternak, sehingga per kelompok kluster ada maksimal 20 orang anggota peternak. Kelompok usaha peternak mitra ini, melakukan pembagian tugas kerjanya dalam mengelola usaha hariannya secara bergiliran. Pola kemitraan ini menurut Nono, O.H. (2011) bahwa keberadaannya memberikan peluang bagi peternak rakyat dan keluarganya untuk melakukan optimalisasi sumber daya lahan dan tenaga kerja keluarganya sehingga akan meningkatkan potensi pendapatannya.

Analisis usahat ernak yang dilakukan menggunakan data asumsi berdasarkan Poetri dkk (2014) bahwa data asumsi sebagai dasar analisis diperoleh melalui suatu kajian, informasi studi pustaka, maupun data lapangan. Asumsi yang digunakan pada penelitian ini adalah eksisting data yang berlaku pada saat penelitian, meliputi harga, biaya dan jumlah sarana produksi, koefisien teknis produksi ternak serta harga dan jumlah hasil produksi. Penggunaan asumsi bunga bank 5\% adalah bunga yang berlaku bagi SKIM kredit pengembangan usaha kecil dan menengah yang ditetapkan oleh BI. Sedangkan skala usaha peternakan rakyat sesuai dengan kebijakan pemerintah , maksimal 100 ekor dan pola kemitraan yang dimaksud sesuai dengan Peraturan menteri pertanian No. ‘/2017 tentang kemitraan.

\section{HASIL DAN PEMBAHASAN}

\section{Pola Pemeliharaan Sapi Potong}

Jenis Usaha ternak sapi potong terdiri atas; kegiatan usaha pembibitan, pembiakan, pembesaran, dan penggemukan. Pada dasarnya kegiatan usaha ini merupakan tahapan perlakuan pemeliharaan yang meliputi: (1) Pemeliharaan sapi indukan siap kawin sampai dengan bunting, (2) Pemeliharaan sapi indukan bunting sampai dengan melahirkan, (3) Pemeliharaan sapi indukan dan pedet menyusui sampai dengan penyapihan, (4) Pembesaran anak sapi lepas sapih sampai dengan bakalan/calon indukan, (5) Penggemukan sapi bakalan (jantan) sampai dengan siap potong. Dari lima tahapan tersebut, tahap penggemukan sapi bakalan merupakan bisnis yang paling banyak dilakukan oleh peternak pelaku usaha karena lebih menguntungkan. Hal ini sesuai dengan pendapat Hadi dan Ilham (2002); dan Umiyasih dkk. (2004) melaporkan bahwa usaha pembibitan sapi potong secara finansial memberikan keuntungan yang jauh lebih kecil dibandingkan usaha penggemukan. Hasil penelitian di beberapa provinsi juga memberikan kesimpulan serupa. Benefit Cost Ratio (BCR) untuk usaha penggemukan sapi berkisar 
antara 1,63-1,72, sedangkan untuk usaha pembibitan sebesar 1,62 (Direktorat Jenderal Peternakan 1995). Sekalipun, dihadapkan pada resiko dan ketergantungan terhadap sistem penyediaan sapi bakalannya. Dalam hal ini sangat sedikit peternak pelaku usaha komersial yang tertarik dengan tahapan pemeliharaan pembibitan, indukan bunting dan menyusui, serta pembesaran dengan pertimbangan kurang menguntungkan dan memerlukan waku panjang. Namun demikian, pengembangan sapi potong pada tahapan tersebut banyak dilakukan oleh usaha peternakan rakyat dengan skala kecil dan pola pemeliharaan secara tradisional, hasil yang dicapai dalam menghasilkan daging kurang optimal. Hal ini dilakukan oleh peternakan rakyat, mengingat ternak berfungsi pula sebagai status sosial bagi kehidupan masyarakat di perdesaan.Namun demikian, usaha pembiakan sapi potong yang selama ini dilakukan peternakan rakyat, kiranya harus terus dikembangkan untuk menyangga pemenuhan akan daging sapi. Usaha pembiakan oleh peternakan rakyat perlu dukungan pemerintah melalui upaya pertama melakukan pengembangan di pulau Jawa dan kemudian ke luar Jawa (Hadi dan Ilham, 2002). Secara umum, basis pembibitan sapi potong dilakukan oleh Village Breeding Centre (VBC) yang bercirikan: tidak terstruktur, skala usaha kecil, manajemen sederhana, pemanfaatan teknologi seadanya. Peran pemerintah dimaksudkan untuk mendorong usaha pembibitan rakyat dan sebaiknya usaha pembibitan VBC diarahkan pada pembibitan (Samariyanto, 2004 dalam Sodiq dan Budiono, 2012).

\section{Analisis Usaha Pembiakan Korporasi}

Pada analisis usaha pembiakan sapi potong, sebagai penyediaan sapi betina dara bunting (pregnant heifer) dapat dilakukan oleh Korporasi, dalam hal ini adalah perusahaan Feedloter. Perusahaan melakukan importasi sapi indukan sesuai dengan Permentan No 2/2017. Anakan yang diperoleh dari kelahiran sapi indukan ex impor tersebut dilakukan proses pembuntingan dengan asumsi seperti tampak pada Tabel 1 .

Pada Tabel 1, tampak bahwa harga beli sapi indukan lokal yaitu Rp. 48.250,00/kg berat hidup. Sementara itu penjualan dara bunting seharga Rp. 45.000,00/ $\mathrm{kg}$ mengikuti harga yang berlaku. Terdapat tiga titik kritis pada usaha budidaya pembiakan yang dilakukan oleh perusahaan feedlot yang berpotensi menimbulkan kerugian yaitu proses (1) pemeliharaan indukan bunting impor sampai dengan lepas menyusui, (2) pembesaran (rearing) dan (3) indukan lokal bunting sampai dengan 6 bulan. Sehingga pada proses pemeliharaan di tiga tahap tersebut perlu adanya rekayasa atau skema yang dapat menekan biaya produksi yang tinggi agar usaha ini tetap dapat berjalan. Salah satu upaya yang dilakukan melalui dilakukannya simulasi terhadap penekanan harga pakan untuk indukan bunting yaitu dengan memberikan pakan komplit (campuran konsentrat dengan hijauan), mengingat pakan merupakan komponen paling berpengaruh terhadap biaya produksi. Pakan memiliki kebutuhan yang paling tinggi yakni $60-70 \%$ dari total biaya produksi. Tingginya biaya tersebut maka

Tabel 1. Asumsi Pemeliharaan Indukan Impor sampai. Menghasilkan Indukan Lokal Bunting 6 Bulan oleh Perusahaan Feedlot

\begin{tabular}{|c|c|c|c|c|}
\hline \multirow[b]{2}{*}{ Asumsi } & \multicolumn{4}{|c|}{ Proses Produksi } \\
\hline & $\begin{array}{l}\text { Induk. Bunting Impor } \\
\text { s.d. Menyusui Anak }\end{array}$ & $\begin{array}{c}\text { Anak Betina - Lepas } \\
\text { Sapih }\end{array}$ & $\begin{array}{l}\text { Anak Betina Lepas } \\
\text { Sapih - Dara }\end{array}$ & Induk - Bunting 6 Bulan \\
\hline HPP Beli Sapi (Rp/Ekor) & $16.887 .500,00$ & $4.310 .547,41$ & $5.764 .346,95$ & $14.897 .292,00$ \\
\hline HPP Beli Sapi (Rp/Kg) & $48.250,00$ & - & $38.428,98$ & $42.697,88$ \\
\hline Bobot Beli (Kg) & 350,00 & - & 150,00 & 348,90 \\
\hline Bobot Jual (Kg) & 530,00 & 150,00 & 348,90 & 474,90 \\
\hline Rataan HPT (Kg/e/h) & - & 13,13 & 27,34 & - \\
\hline Rataan Konsentrat $(\mathrm{Kg} / \mathrm{E} / \mathrm{H})$ & - & 0,82 & 5,15 & - \\
\hline Rataan Pakan Komplit (Kg/E/H) & 35,25 & - & - & 35,14 \\
\hline Harga HPT(Rp/Kg) & - & 250,00 & 250,00 & - \\
\hline Harga Konsentrat $(\mathrm{Rp} / \mathrm{Kg})$ & - & $2.800,00$ & $2.800,00$ & - \\
\hline Harga Pakan Komplit (Rp/Kg) & 600,00 & - & - & 600,00 \\
\hline Harga Jual Sapi (Rp/Kg) & $45.000,00$ & $46.666,67$ & $42.850,00$ & $45.000,00$ \\
\hline Biaya Sewa Kandang (Rp/E/Hr) & 684,93 & 684,93 & 684,93 & 684,93 \\
\hline Biaya T.K/ Overhead (Rp/E) & $1.666,67$ & 833,33 & 833,33 & $1.666,67$ \\
\hline Lama Pelihara (Hari) & - & 150,00 & 390,00 & - \\
\hline Lama (Hari) Bunting & 300,00 & - & - & 210,00 \\
\hline Lama (Hari) Menyusui & 150,00 & - & - & - \\
\hline Biaya Obat (Rp/ Ekor) & $10.000,00$ & $10.000,00$ & $10.000,00$ & $10.000,00$ \\
\hline $\mathrm{ADG}(\mathrm{Kg})$ & 1,20 & - & 0,51 & 0,60 \\
\hline Calving Rate & 0,63 & - & - & - \\
\hline Kematian (\%) & - & $5 \%$ & - & - \\
\hline Bunga Bank (\%) & $5 \%$ & $5 \%$ & $5 \%$ & $5 \%$ \\
\hline
\end{tabular}


mengharuskan peternak untuk menjadikan pakan sebagai hal yang harus diperhatikan dalam usaha peternakan. Bahan pakan harus mempunyai harga yang layak dan diusahakan jangan bersaing dengan kebutuhan manusia yang sangat utama. Bahan pakan harus dapat diganti oleh bahan pakan lain yang kandungan zat- zat makanannya hampir sama. Bahan pakan tidak mengandung racun dan tidak dipalsukan atau tidak menampakan perbedaan warna, bau, atau rasa dari keadaan normalnya.

Hasil simulasi yang dilakukan, ditemukan bahwa kemampuan usaha ini dapat berjalan jika harga pakan untuk pemeliharaan indukan bunting pada harga maksimal Rp.600/kg, sehingga diperlukan adanya subsidi dari perusahaan feedlot sebesar Rp. 400/kg untuk pakan pada proses pemeliharaan indukan bunting. Selain pakan, lahan juga tidak diperhitungkan dalam analisis ini. Sedangkan, hargaharga lainnya mengikuti kondisi yang berlaku saat penelitian ini. Sejalan dengan pendapat Budihardjo dkk (2011) bahwa pakan memberikan kontribusi biaya terbesar dalam usahaternak sapi potong.

Berdasarkan asumsi pada Tabel 1, maka dilakukan analisis usahaternak seperti tampak pada Tabel 2. Berdasarkan Tabel 2, apabila analisisnya dilakukan secara parsial, tampak bahwa perusahaan feedlot, pada pemeliharaan induk impor bunting sampai melahirkan anak lepas sapih posisinya merugi 15\%. Di sisi lain, pada pemeliharaan anak betina lepas sapih mendapatkan keuntungan sebesar $21,44 \%$. Sedangkan pemeliharan dara memperoleh keuntungan sebesar $0,36 \%$ dan penjualan dara bunting lokal sebesar 4,12\%.

Namun, karena pemeliharaan ini terus berlanjut, maka sesungguhnya biaya perolehan sapi dari setiap proses produksi mengacu pada HPP (biaya perolehan ditambah biaya pemeliharaan) bukan harga jual (setelah ditambah keuntungan).Kerugian pada tahapan pemeliharaan sapi impor bunting menjadi harga perolehananak sapi yang dilahirkan seharga $\mathrm{Rp}$. 4.310.547,41 pada pemeliharaan anak betina lepas sapih dan menjadi tanggungan pada proses pemeliharaan anak sampai dengan lepas sapih. Demikian juga halnya pada pemeliharaan anak lepas sapih sampai sapi dara. Kesimpulannya pada system pemeliharaan ini perusahaan feedlot akan mendapatkan keuntungan usaha sebesar $4,12 \%$, tatkala menjual sapi indukan lokal bunting.

\section{Analisis Usahaternak Pola kemitraan Tahap ke-1}

Dalam pola kemitraan tahap ke-1 asumsi yang digunakan berdasarkan hasil survey seperti pada Tabel 3.tampak bahwa agar usaha pada tahapan ini dapat berjalan dan menguntungkan bagi peternak, maka harga beli indukan bunting 6 bulan dipastikan tidak lebih dari Rp.45.000,-/kg. Hal ini berdasarkan hasil analisis terhadap situasi dan kondisi lapangan pada saat penelitian berlangsung. Harga ini, merupakan hasil simulasi yang paling rasional. Pada tahapan ini, setiap nilai kerugian per ekor pada proses pemeliharaan sapi indukan bunting sampai dengan menyusui anaknya yang dipelihara, menjadi nilai acuan harga anak yang baru lahir, sehingga harga anak yang baru lahir per ekor yaitu sebesar Rp. 4.870.173,01merupakan nilai kerugian dari penjualan induk setelah proses menyusui. Harga pedet tersebut, merupakan harga ideal yang berlaku dilapangan. Sedangkan bobot jual pedet lepas sapih terdapat perbedaan antara sapi pedet betina Rp. 46.666,67/ $\mathrm{kg}$ berat hidup, lebih murah daripada harga pedet jantan dengan harga Rp. 53.333,33/Kg berat hidup. Selanjutnya, berdasarkan asumsi-asumsi tersebut pada tabel 3, dilakukan analisis usaha ternak yang tampak pada Tabel 4.

Pada Tabel 4, tampak bahwa terdapat dua kegiatan budidaya pada tahapan ini yaitu pemeliharaan sapi indukan bunting 6 bulan sampai dengan indukan setelah menyusui (lepas sapih) dan pemeliharaan pedet (anak lahir sampai anak lepas sapih). Dari dua aktivitas tersebut pemeliharaan indukan bunting, ternyata merupakan aktivitas usaha

Tabel 2. Analisis UsahaTernak Pemeliharaan Indukan Impor sampai Menghasilkan Indukan Lokal Bunting 6 Bulan oleh Perusahaan Feedlot

\begin{tabular}{|c|c|c|c|c|c|c|}
\hline \multirow{3}{*}{ Asumsi } & \multicolumn{6}{|c|}{ Proses Produksi } \\
\hline & \multicolumn{2}{|c|}{$\begin{array}{c}\text { Induk. Bunting Impor s.d. } \\
\text { Menyusui Anak }\end{array}$} & \multirow{2}{*}{$\begin{array}{c}\text { Anak Betina- } \\
\text { Lepas Sapih } \\
\text { Per Ekor }\end{array}$} & \multirow{2}{*}{$\begin{array}{c}\text { Anak Betina Lepas } \\
\text { Sapih - Dara } \\
\text { Per Ekor }\end{array}$} & \multicolumn{2}{|c|}{ Induk - Bunting 6 Bulan } \\
\hline & Per Ekor & 2000 ekor & & & Per Ekor & 1000 ekor \\
\hline $\mathrm{HPP}(\mathrm{Rp} / \mathrm{Kg})$ & 53.133 & - & $36.507,53$ & $42.697,88$ & $42.797,68$ & - \\
\hline HPP + Ongkos (Rp/Kg) & - & - & - & - & $43.234,61$ & - \\
\hline $\begin{array}{l}\text { HPP Setelah Kematian } \\
5 \%\end{array}$ & - & - & $38.428,98$ & $42.697,88$ & - & - \\
\hline $\mathrm{L} / \mathrm{R}(\mathrm{Rp} / \mathrm{Kg})$ & -8.133 & -8.621 .094 .819 & $8.237,69$ & 152,12 & $1.765,39$ & $838.383 .111,93$ \\
\hline L/R(Rp/ Ekor/ Prod) & -4.310 .547 & -8.621 .094 .819 & $1.235 .653,05$ & $53.073,00$ & $838.383,11$ & $838.383 .111,93$ \\
\hline L/R (Rp/ Ekor/ Bulan) & -538.818 & -1.077 .636 .852 & $154.456,63$ & $2.527,29$ & $104.797,89$ & $104.797 .888,99$ \\
\hline Persentase $(\%)$ & $-15 \%$ & - & $21,44 \%$ & $0,36 \%$ & $4,12 \%$ & - \\
\hline
\end{tabular}


yang merugikan (-14\%). Kerugian ini, ditutupi oleh keuntungan dari penjualan anak lepas sapih, yaitu anak betina dan jantan (Rp. 4.870.173/ekor pedet). Sesungguhnya, HPP indukan setelah lepas sapih sebesar Rp.52.493,00 per kg berat hidup, sedangkan harga jual nya adalah Rp.45.000,-per kg sehingga nilai kerugian daripada induk setelah menyusui menjadi nilai perolehan anak pada proses budidaya pemeliharaan anak sampai dengan lepas sapih.

Tabel 3. Asumsi Analisis Usahaternak Model Pemeliharaan Tahap-1

\begin{tabular}{|c|c|c|c|}
\hline \multirow[b]{2}{*}{ Asumsi } & \multicolumn{3}{|c|}{ Proses Produksi } \\
\hline & $\begin{array}{c}\text { Induk Bunting } 6 \text { Bulan - Lepas } \\
\text { Menyusui }\end{array}$ & Anak Betina - Lepas Sapih & Anak Jantan - Lepas Sapih \\
\hline HPP Beli Sapi (Rp/Ekor) & $21.150 .000,00$ & $4.870 .173,01$ & $4.870 .173,01$ \\
\hline HPP Beli Sapi (Rp/Kg) & $45.000,00$ & - & - \\
\hline Bobot Beli (Kg) & 470,00 & - & - \\
\hline Bobot Jual (Kg) & 650,00 & 150,00 & 150,00 \\
\hline Rata-Rata Hpt (Kg/e/h) & - & 13,13 & 13,13 \\
\hline Rata-Rata Konsentrat $(\mathrm{Kg} / \mathrm{E} / \mathrm{H})$ & - & 0,82 & 0,82 \\
\hline Rata-Rata Pakan Komplit (Kg/E/H) & 47,34 & - & - \\
\hline Harga $\operatorname{Hpt}(\mathrm{Rp} / \mathrm{Kg})$ & - & 250,00 & 250,00 \\
\hline Harga Konsentrat $(\mathrm{Rp} / \mathrm{Kg})$ & - & $2.800,00$ & $2.800,00$ \\
\hline Harga Pakan Komplit (Rp/Kg) & $1.000,00$ & - & - \\
\hline Harga Jual Sapi (Rp/Kg) & $45.000,00$ & $46.666,67$ & $53.333,33$ \\
\hline Biaya Sewa Kandang (Rp/Ekor/Hr) & 684,93 & 684,93 & 684,93 \\
\hline Biaya T. Kerja/ Overhead (Rp/E) & $1.666,67$ & 833,33 & 833,33 \\
\hline Lama Piara (Hari) & - & 150,00 & 150,00 \\
\hline Lama Piara (Hari) Bunting & 90,00 & - & - \\
\hline Lama Piara (Hari) Menyusui & 150,00 & - & - \\
\hline Biaya Obat (Rp/ Ekor) & $10.000,00$ & $10.000,00$ & $10.000,00$ \\
\hline $\operatorname{Adg}(\mathrm{Kg})$ & 1,20 & - & - \\
\hline Calving Rate & 0,63 & - & - \\
\hline Kematian $(\%)$ & - & $5 \%$ & $5 \%$ \\
\hline Bunga Bank (5\%) & $5 \%$ & $5 \%$ & $5 \%$ \\
\hline
\end{tabular}

Tabel 4. Analisis Usahaternak Model Kemitraan Pemeliharaan Tahap-1

\begin{tabular}{|c|c|c|c|c|c|c|}
\hline \multirow{3}{*}{ Asumsi } & \multicolumn{6}{|c|}{ Proses Produksi } \\
\hline & \multicolumn{2}{|c|}{$\begin{array}{c}\text { Induk Bunting } 6 \text { Bulan - } \\
\text { Lepas Menyusui }\end{array}$} & \multicolumn{2}{|c|}{ Anak Betina - Lepas Sapih } & \multicolumn{2}{|c|}{ Anak Jantan - Lepas Sapih } \\
\hline & Per Ekor & 100 ekor & Per Ekor & 100 ekor & Per Ekor & 100 ekor \\
\hline $\operatorname{HPP}(\mathrm{Rp} / \mathrm{Kg})$ & 52.173 & - & $40.300,55$ & - & $40.300,55$ & - \\
\hline $\begin{array}{l}\mathrm{HPP}+\text { Ongkos }(\mathrm{Rp} / \\
\mathrm{Kg})\end{array}$ & 52.493 & - & $40.992,22$ & - & $40.992,22$ & - \\
\hline $\begin{array}{l}\text { HPP Setelah } \\
\text { Kematian 5\% }\end{array}$ & - & - & $43.149,70$ & - & $43.149,70$ & - \\
\hline $\mathrm{L} / \mathrm{R}(\mathrm{Rp} / \mathrm{Kg})$ & -7.493 & -487.017 .301 & $3.516,97$ & $26.377 .247,60$ & $10.183,63$ & $76.377 .247,60$ \\
\hline $\begin{array}{l}\mathrm{L} / \mathrm{R}(\mathrm{Rp} / \mathrm{Ek} / \text { Periode } \\
\text { Prod })\end{array}$ & -4.870 .173 & -487.017 .301 & $527.544,95$ & $26.377 .247,60$ & $1.527 .544,95$ & $76.377 .247,60$ \\
\hline L/R (Rp/ Ekor/Bln) & -608.772 & -60.877 .163 & $65.943,12$ & $3.297 .155,95$ & $190.943,12$ & $9.547 .155,95$ \\
\hline Persentase $(\%)$ & -14 & - & 8,15 & - & 23,60 & - \\
\hline $\begin{array}{l}\text { Penerimaan Peternak } \\
\text { Total (Rp) }\end{array}$ & -4.470 .173 & -447.017 .301 & $1.144 .732,45$ & $57.236 .622,60$ & $2.144 .732,45$ & $107.236 .622,60$ \\
\hline $\begin{array}{l}\text { Penerimaan Peternak } \\
\text { Bulanan (Rp) }\end{array}$ & -558.772 & -55.877 .163 & $228.946,49$ & $11.447 .324,52$ & $428.946,49$ & $21.447 .324,52$ \\
\hline
\end{tabular}


Pada analisis usahaternak tahap ini, ternyata keuntungan pemeliharaan pedet betina sebesar $8,15 \%$ dan pedet jantan $23,6 \%$, atau rata-rata sebesar $15,88 \%$ dalam satu periode produksi selama 8 bulan. Tingginya pendapatan pemeliharaan pedet jantan disebabkan karena harga sapi pedet jantan lebih mahal daripada pedet betina. Secara teknis mekanisme operasional kemitraan pembiakan sapi pada tahap-1 seperti tampak pada gambar 2 .

\section{Mekanisme Operasional kemitraan sebagai} berikut:

1. Pembuatan MoU, dilakukan antara pihak bank dan perusahaan feedlot berperan sebagai pihak ketiga yang menjamin pasar, teknologi pakan dan pembinaan/pendampingan terhadap kelompok peternak (Kluster).

2. Peternak yang ditunjuk mewakili kelompok peternak (kluster) mengajukan kredit ke bank atau koperasi atau BUMDesa yang menggunakan lembaga ekonomi desa berbadan hukum.

3. Bank melakukan survey (appraisal) terhadap kelompok peternak (kluster) untuk memperoleh persetujuan, pengikatan kontrak dan pencairan dana.

4. Peternak melalui bank yang ditunjuk melakukan pembayaran pembelian sapi dara bunting kepada perusahaan feedlot.

5. Perusahaan feedlot mensupply sapi indukan bunting 6 bulan setelah peternak melakukan pembayaran (cash and carry).

6. Perusahaan feedlot melakukan pembinaan/ pendampingan pemeliharaan dan pemasaran, serta berperan sebagai: a) Pemberi referensi peternak (kluster) ke bank

b) Penyedia sapi dara bunting.

c) Pendamping peternak dalam proses produksi (budidaya).

d) Pembeli hasil panen poin $\mathrm{C}$.

7. Setelah pedet umur 4 bulan, peternak menjual pedet dan induknya kepada perusahaan feedlot dengan harga pasar yang berlaku.

8. Pembayaran hasil penjualan pedet dan induk dibayarkan oleh bank yang dananya berasal dari pembayaran bunga dan pinjaman pokok.

\section{Analisis Usahaternak Pola kemitraan Tahap ke-2}

Pada analisis usahaternak model kemitraan pemeliharaan pada tahap-2 ini menghasilkan sapi bakalan/dara berumur 18 bulan, dengan asumsi yang tampak pada Tabel 5 . Asumsi yang digunakan didasarkan kepada situasi dan kondisi serta fenomena yang terjadi selama kajian berlangsung. Pada tahapan ini, pemeliharaan sapi indukan bunting 6 bulan sampai dengan menghasilkan bakalan.Proses budidaya yang dilakukan dibagi menjadi 3 yaitu (1) pemeliharaan indukan bunting, melahirkan sampai dengan menyusui; (2) pemeliharaan pedet sampai dengan lepas sapih; dan (3) Pembesaran anak lepas sapih sampai dengan menjadi bakalan umur 18 bulan sehingga total lama budidaya yang dilakukan adalah 21 bulan.

Pada Tabel 5, tampak asumsi nilai acuan anak lepas sapih pada proses tahapan yang ke tiga (pembesaran anak) adalah HPP anak lepas sapih jantan dan betina bukan harga jual anak lepas sapih yaitu seharga Rp. 4.870.173,01per ekor. Hal ini karena anak lepas sapih yang menjadi input pada aktivitas budidaya ke 2 tidak dijual melainkan

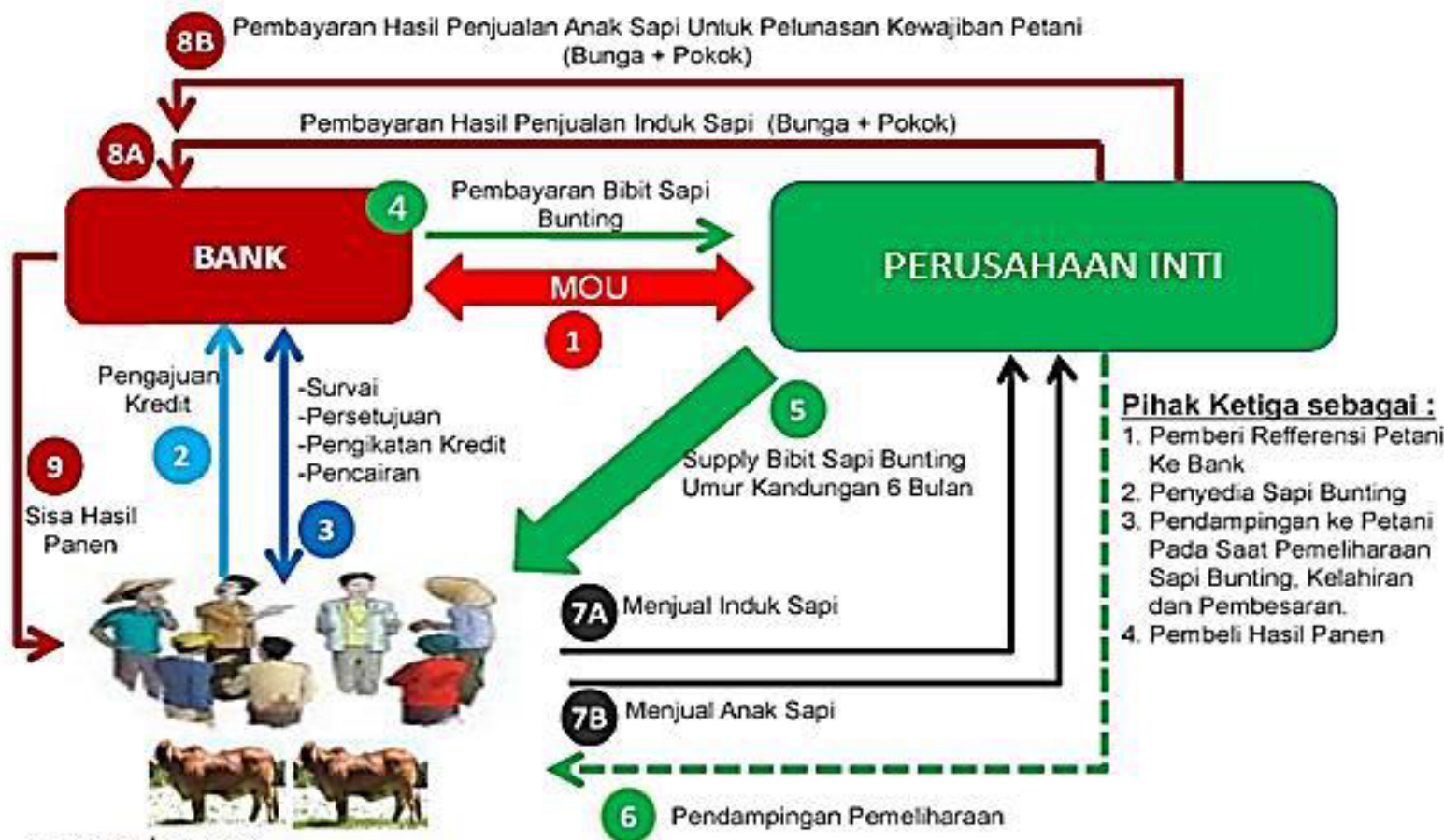

PETANI/BUMP

Gambar 2. Mekanisme Opersional Kemitraan Tahap ke-1 (Agus dkk, 2017) 
dilanjutkan aktivitas budidayanya sampai dengan menjadi sapi bakalan jantan/dara, sehingga acuan nilai perolehannya adalah HPP bukan pada harga jual. Sedangkan harga jual anak sapi jantan dan betina, harga jualnya berbeda secara signifikan yaitu $\mathrm{Rp}$. $46.667,67 / \mathrm{Kg}$ berat hidup untuk pedet sapi betina dan Rp. 53.333,33/kg untuk pedet sapi jantan.

Berdasarkan asumsi pada Tabel 5, dilakukan analisis usahatani seperti tampak pada table 6. Pada
Tabel 6, dapat diungkap bahwa, kemitraan usaha ternak sapi potong pada tahapan-2 ternyata merugikan sebesar 3,54\%. Seperti halnya pada analisis terdahulu, bahwa pemeliharaan Induk Bunting sampai melahirkan dan pembesaran usaha adalah dua kegiatan yang merugikan. Sebenarnya, ternyata hanya kegiatan usaha pemeliharaan pembesaran pedet yang menguntungkan, yaitu sejak dilahirkan sampai dengan lepas sapih.

Tabel 5. Asumsi Analisis Usahaternak Model Pemeliharaan Tahap-2

\begin{tabular}{|c|c|c|c|c|}
\hline \multirow[b]{2}{*}{ Asumsi } & \multicolumn{4}{|c|}{ Proses Produksi } \\
\hline & $\begin{array}{c}\text { Induk Bunting } 6 \text { Bulan - } \\
\text { Lepas sapih }\end{array}$ & $\begin{array}{l}\text { Anak Betina - } \\
\text { Lepas Sapih }\end{array}$ & $\begin{array}{c}\text { Anak Jantan - Lepas } \\
\text { Sapih }\end{array}$ & $\begin{array}{l}\text { Lepas Sapih - } \\
\text { Bakalan }\end{array}$ \\
\hline HPP Beli Sapi (Rp/Ekor) & $21.150 .000,00$ & $4.870 .173,01$ & $4.870 .173,01$ & $6.363 .244,52$ \\
\hline HPP Beli Sapi (Rp/Kg) & $45.000,00$ & - & - & $42.421,63$ \\
\hline Bobot Beli (Kg) & 470,00 & - & - & 150,00 \\
\hline Bobot Jual (Kg) & 650,00 & 150,00 & 150,00 & 352,80 \\
\hline Rata-Rata HPT (Kg/e/h) & - & 13,13 & 13,13 & 27,34 \\
\hline Rata-Rata Konsentrat $(\mathrm{Kg} / \mathrm{E} / \mathrm{H})$ & - & 0,82 & 0,82 & 5,15 \\
\hline Rata-Rata Pakan Komplit (Kg/E/H) & 47,34 & - & - & - \\
\hline Harga HPT(Rp/Kg) & - & 250,00 & 250,00 & 250,00 \\
\hline Harga Konsentrat $(\mathrm{Rp} / \mathrm{Kg})$ & - & $2.800,00$ & $2.800,00$ & $2.800,00$ \\
\hline Harga Pakan Komplit (Rp/Kg) & $1.000,00$ & - & - & - \\
\hline Harga Jual Sapi (Rp/Kg) & $45.000,00$ & $46.666,67$ & $53.333,33$ & $42.850,00$ \\
\hline Biaya Sewa Kandang (Rp/Ekor/Hr) & 684,93 & 684,93 & 684,93 & 684,93 \\
\hline Biaya T. Kerja/ Overhead (Rp/E) & $1.666,67$ & 833,33 & 833,33 & 833,33 \\
\hline Lama Piara (Hari) & - & 150,00 & 150,00 & 390,00 \\
\hline Lama Piara (Hari) Bunting & 90,00 & - & - & - \\
\hline Lama Piara (Hari) Menyusui & 150,00 & - & - & - \\
\hline Biaya Obat (Rp/ Ekor) & $10.000,00$ & $10.000,00$ & $10.000,00$ & $10.000,00$ \\
\hline $\operatorname{Adg}(\mathrm{Kg})$ & 1,20 & - & - & - \\
\hline Calving Rate & 0,63 & - & - & - \\
\hline Kematian (\%) & - & $5 \%$ & $5 \%$ & - \\
\hline Bunga Bank (5\%) & $5 \%$ & $5 \%$ & $5 \%$ & $5 \%$ \\
\hline
\end{tabular}

Tabel 6. Analisis Usahaternak Model Kemitraan pada Pemeliharaan Tahap-2

\begin{tabular}{lrr}
\hline \multirow{2}{*}{ Asumsi } & \multicolumn{2}{c}{ Proses Produksi } \\
\cline { 2 - 3 } & \multicolumn{2}{c}{ Lepas Sapih - Bakalan } \\
\cline { 2 - 3 } & \multicolumn{2}{c}{ Per Ekor } \\
\hline HPP (Rp/ Kg) & 43.952 & ekor \\
HPP + Ongkos (Rp/Kg) & 44.422 & - \\
HPP Setelah Kematian 5\% & - & - \\
Laba/ Rugi (Rp/ Kg) & -1.572 & -39.966 .621 .448 \\
Laba/ Rugi (Rp/ Ekor/ Periode Produksi) & -554.691 & -55.469 .120 \\
Laba/ Rugi (Rp/ Ekor/ Bulan) & -26.414 & -2.641 .387 \\
Persentase (\%) & $-3,54 \%$ & - \\
Penerimaan Peternak Total (Rp) & 2.436 .324 & 243.632 .443 \\
Penerimaan Peternak Bulanan (Rp) & 187.410 & 18.740 .957 \\
\hline
\end{tabular}


Mekanisme operasional kemitraan pemeliharaan sapi pada tahap-2 secara skematis tampak pada gambar 3.

\section{Mekanisme Operasional kemitraan sebagai} berikut:

1. Pembuatan MoU antara pihak bank dan perusahaan feedlot yang berperan sebagai pihak ketiga.

2. Peternak yang ditunjuk oleh kelompok Kluster mengajukan kredit ke bank.

3. Bank melakukan survey (appraisal), persetujuan, pengikatan kontrak dan pencairan dana.

4. Peternak melalui bank melakukan pembayaran pembelian sapi dara bunting 6 bulan kepada perusahaan feedlot.

5. Perusahaan feedlot mensupply sapi dara bunting 6 bulan setelah peternak kluster melakukan pembayaran (cash and carry).

6. Perusahaan feedlot melakukan pendampingan pemeliharaan dan berperan sebagai: a. Pemberi referensi peternak kluster kepada bank

b. Penyedia sapi dara bunting

c. Pendamping peternak dalam proses produksi dan Pembeli hasil panen.

7. Setelah pedet mencapai umur bakalan atau umur 18bulan, peternak menjual sapi bakalan tersebut kepada perusahaan feedlot.

8. Pembayaran hasil penjualan sapi bakalan tersebut dibayarkan oleh bank yang dananya berasal dari pembayaran bunga dan pinjaman pokok.

Analisis Usahaternak Model Kemitraan Tahap ke-3

Asumsi Pada Model Kemitraan Pemeliharaan Tahap-3 yaitu pemeliharaan indukan bunting 6 bulan sampai dengan menghasilkan sapi siap potong. Lama budidaya yang dilakukan adalah 25 bulan, dan asumsi-asumsi tersebut tampak pada Tabel 7.

Gambar3. Mekanisme Opersional Kemitraan pemeliharaan Tahap-2 (Agus, dkk, 2017)

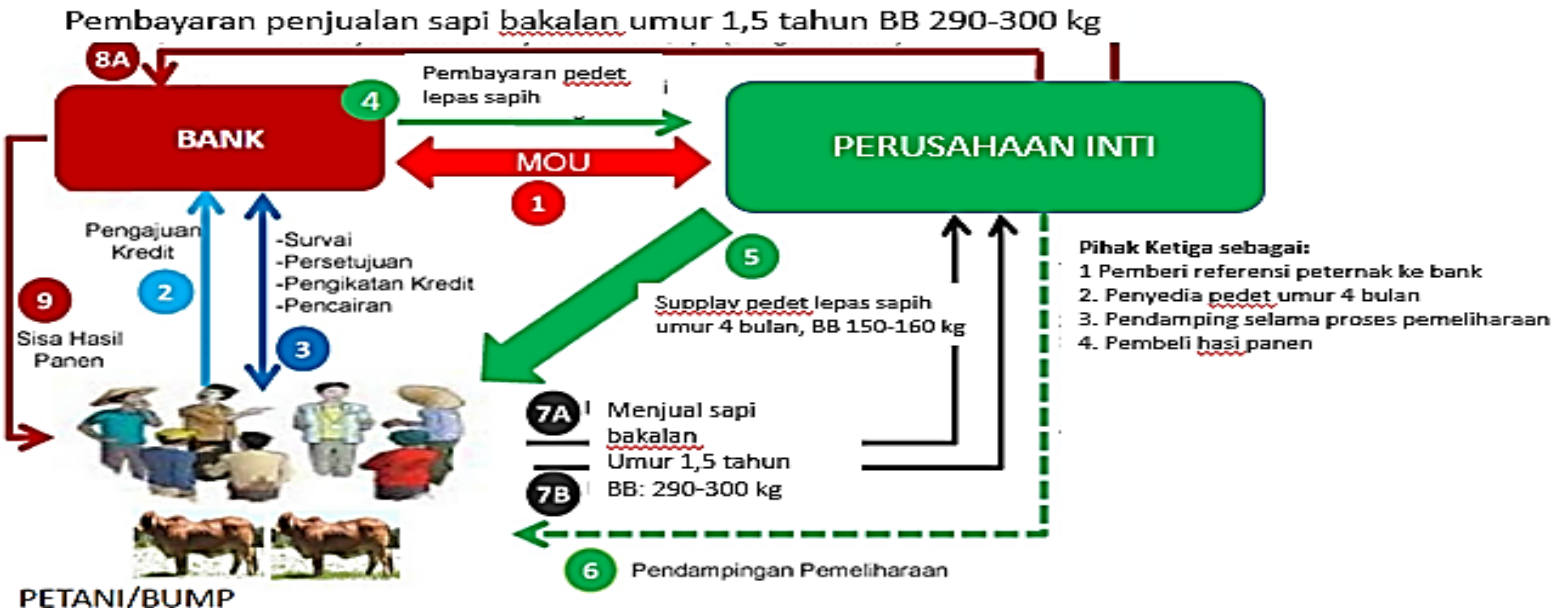

Tabel 7. Asumsi Analisis Usahaternak Model Kemitraan Tahap-3

\begin{tabular}{|c|c|c|c|c|c|}
\hline \multirow[b]{2}{*}{ Asumsi } & \multicolumn{5}{|c|}{ Proses Produksi } \\
\hline & $\begin{array}{c}\text { Bunting } 6 \text { Bulan - } \\
\text { Lepas Menyusui }\end{array}$ & $\begin{array}{c}\text { Anak Betina - } \\
\text { Lepas Sapih }\end{array}$ & $\begin{array}{l}\text { Anak Jantan - } \\
\text { Lepas Sapih }\end{array}$ & $\begin{array}{l}\text { Lepas Sapih - } \\
\text { Bakalan }\end{array}$ & $\begin{array}{c}\text { Bakalan - Sapi } \\
\text { Siap Potong }\end{array}$ \\
\hline HPP Beli Sapi (Rp/Ekor) & 21.150 .000 & 4.870 .173 & 4.870 .173 & 6.363 .245 & 15.506 .171 \\
\hline HPP Beli Sapi (Rp/Kg) & 45.000 & - & - & 42.422 & 43.952 \\
\hline Bobot Beli (Kg) & 470 & - & - & 150 & 353 \\
\hline Bobot Jual (Kg) & 650 & 150 & 150 & 353 & 497 \\
\hline Rata-Rata Hpt (Kg/e/h) & - & 13 & 13 & 27 & 39 \\
\hline Rata-Rata Konsentrat $(\mathrm{Kg} / \mathrm{E} / \mathrm{H})$ & - & 1 & 1 & 5 & 7 \\
\hline Rata-Rata Pakan Komplit (Kg/E/H) & 47 & - & - & - & - \\
\hline Harga $\mathrm{Hpt}(\mathrm{Rp} / \mathrm{Kg})$ & - & 250 & 250 & 250 & 250 \\
\hline Harga Konsentrat $(\mathrm{Rp} / \mathrm{Kg})$ & - & 2.800 & 2.800 & 2.800 & 2.800 \\
\hline Harga Pakan Komplit (Rp/Kg) & 1.000 & - & - & - & - \\
\hline Harga Jual Sapi (Rp/Kg) & 45.000 & 46.667 & 53.333 & 42.850 & 42.500 \\
\hline Biaya T. Kerja/ Overhead (Rp/E) & 685 & 685 & 685 & 685 & 685 \\
\hline Biaya Overhead (Rp/E) & 1.667 & 833 & 833 & 833 & 833 \\
\hline Lama Piara (Hari) & - & 150 & 150 & 390 & 120 \\
\hline Lama (Hari) Bunting & 90 & - & - & - & - \\
\hline Lama (Hari) Menyusui & 150 & - & - & - & - \\
\hline Biaya Obat (Rp/ Ekor) & 10.000 & 10.000 & 10.000 & 10.000 & 10.000 \\
\hline $\operatorname{Adg}(\mathrm{Kg})$ & 1 & - & - & - & - \\
\hline Calving Rate & 1 & - & - & - & - \\
\hline Kematian (\%) & - & $5 \%$ & $5 \%$ & - & - \\
\hline Bunga Bank (5\%) & $5 \%$ & $5 \%$ & $5 \%$ & $5 \%$ & $12 \%$ \\
\hline
\end{tabular}


Pada Tabel 7, nilai acuan sapi bakalan pada proses penggemukan, adalah HPP bakalan bukan harga jual bakalan yaitu seharga Rp. 15.506.171,00per ekor atau Rp. 43.952,00 per kg. Hal ini dilakukan karena bakalan yang menjadi input pada aktivitas budidaya penggemukan tidak dijual melainkan dilanjutkan aktivitas budidayanya sampai dengan menjadi sapi siap potong, sehingga acuan nilai perolehannya adalah HPP bukan pada harga jual. Selanjutnya suku bunga bank yang dilakukan dibagi dua yaitu sebesar $5 \%$ per tahun diperuntukkan bagi budidaya pengembangbiakan dan bunga bank komersial sebesar $12 \%$ per tahun bagi usaha penggemukan.

Berdasarkan asumsi yang tertera pada Tabel 7, dilakukan analisis usahaternak sapi potong, seperti tampak pada Tabel 8.Berdasarkan pada Tabel 8, tampak bahwa keuntungan usaha yang diperoleh peternak rakyat yang melakukan usaha kemitraan dengan Model tahap-3 adalah sebesar 4,13\% atau senilai Rp. 2.095.712,00 per ekor. Jika dalam satu kluster sejumlah 100 ekor maka keuntungan yang didapatkan senilai Rp.209.571.150,00 dalam satu periode produksi. Secara nilai aktivitas budidaya ini memberikan nilai tambah lebih baik daripada Model tahap-1 dan tahap-2. Namun demikian, yang menjadi kendala bagi usaha ini adalah rentang waktu proses budidaya yang relatif lebih lama akan menyebabkan putaran cashflow nya lebih lambat. Untuk petani maupun peternak yang memiliki kebutuhan harian yang harus dipenuhi memerlukan pemasukan yang relatif lebih cepat. Untuk itu diperlukan pengaturan replacement stock dan struktur populasi yang ditentukan oleh tingkat keberhasilan mengatur sistem perkawinannya.
Tabel 8. Analisis Usahaternak Model Kemitraan Pemeliharaan Tahap-3

\begin{tabular}{lcc}
\hline \multirow{2}{*}{ Asumsi } & \multicolumn{2}{c}{ Proses Produksi } \\
& \multicolumn{2}{c}{ Bakalan - Siap Potong } \\
\cline { 2 - 3 } & Per Ekor & 100 ekor \\
\hline HPP (Rp/ Kg) & 40.395 & - \\
HPP + Ongkos (Rp/Kg) & 40.813 & - \\
HPP Setelah Kematian 5\% & - & - \\
Laba/ Rugi (Rp/ Kg) & 1.687 & 83.808 .650 \\
$\begin{array}{l}\text { Laba/ Rugi (Rp/ Ekor/ } \\
\text { Periode Produksi) }\end{array}$ & 838.087 & 83.808 .650 \\
$\begin{array}{l}\text { Laba/ Rugi (Rp/ Ekor/ } \\
\text { Bulan) }\end{array}$ & 209.522 & 20.952 .163 \\
$\begin{array}{l}\text { Persentase (\%) } \\
\text { Penerimaan Peternak Total } \\
\text { (Rp) }\end{array}$ & $4,13 \%$ & - \\
$\begin{array}{l}\text { Penerimaan Peternak } \\
\text { Bulanan (Rp) }\end{array}$ & 2.095 .712 & 209.571 .150 \\
\hline
\end{tabular}

Secara teknis operasional pola kemitraan pemeliharaan sapi tahap ke-3 tampak pada gambar 4 .

Mekanisme Operasional kemitraan sebagai berikut:

1. Pembuatan MoU antara pihak bank dan perusahaan feedlot yang berperan sebagai pihak ketiga

2. Peternak yang ditunjuk oleh kelompok kluster mengajukan kredit ke bank

3. Bank melakukan survey (Apraisal), persetujuan, pengikatan kontrak dan pencairan dana

4. Peternak melalui bank melakukan pembayaran pembelian dara bunting 6 bulan kepada perusahaan Feedlot.

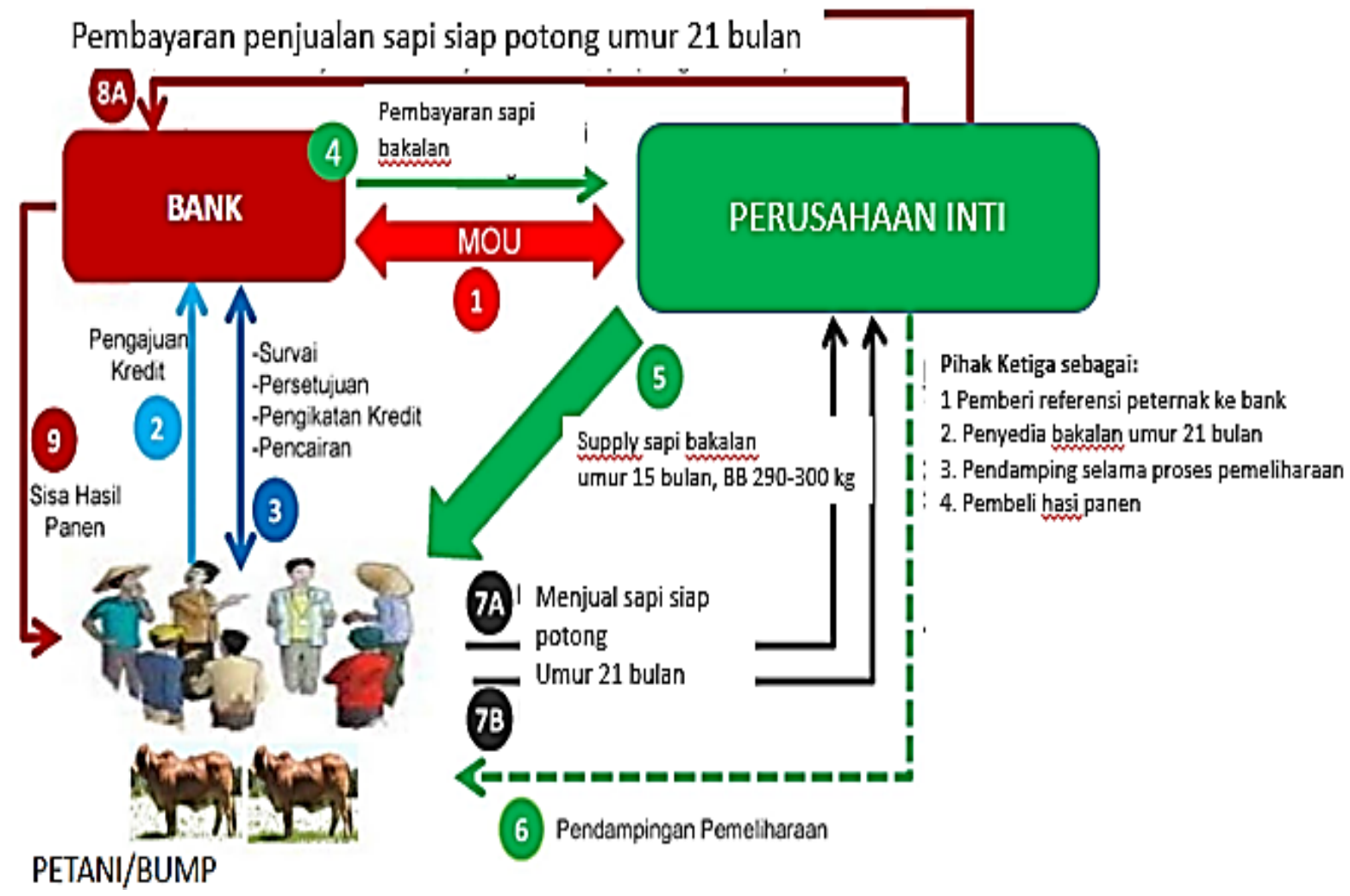

Gambar 4. Mekanisme Opersional Kemitraan pemeliharaan Tahap ke-3(Agus dkk, 2017) 
Berdasarkan ketiga model kemitraan, maka pemeliharaan tahap 1 dan 3 yang direkomendasikan untuk dilaksanakan oleh perusahaan feedlot bersama peternak rakyat sebagai kelompok peternak klaster. Hal ini disebabkan kedua model kemitraan ini menguntungkan secara finansial bagi kedua belah pihak. Hal ini sejalan dengan hasil penelitian Suryana (2009) dan bahwa peningkatan permintaan terhadap daging sapi membuka peluang bagi pengembangan sapi potong lokal dengan skala agribisnis melalui pola kemitraan. Sistem agribisnis sapi potong merupakan kegiatan yang mengintegrasikan pembangunan pertanian, industri, dan jasa secara simultan dalam suatu kluster. Selain itu menurut Tawaf dan Suryadi (2010) bahwa usaha penggemukan sapi potong yang dikelola oleh peternakan rakyat memiliki keunggulan komparatif, sehingga secara finansial menguntungkan.

\section{SIMPULAN}

Berdasarkan hasil analisis terhadap tiga model kemitraan pada pola usaha pembiakan usahaternak sapi potong rakyat sebagai berikut: Usaha pembiakan sapi potong tidak dapat dilakukan secara intensif yang ditunjukan oleh tingkat keuntungan yang negative, hal ini mengingat mahalnya biaya pakan yang harus disediakan. Oleh karenanya, usaha ini sangat cocok jika dilakukan secara ekstensif; Agar usaha pembiakan dapat berjalan dengan baik pada pola usaha intensif, maka diperlukan kontribusi perusahaan feedlot terhadap biaya pakan sebesar Rp 400,00/kg dan lahan yang digunakan sebagai kandang. Selain itu, pemerintah harus mampu berkontribusi dengan fasilitas bunga bank $5 \%$ per tahun dengan tenggang waktu pembayaran hutang 18 bulan.

Dari tiga model kemitraan pembiakan yang dianalisis, maka pola kemitraan tahap pertama dan ketiga yang dapat direkomendasi untuk direalisasikan dengan skala usaha per kelompok 100 ekor.

\section{UCAPAN TERIMA KASIH}

Terima kasih disampaikan kepada Prof. Ir. I Gede Suparta Budisatria, M.Sc., Ph.D. sebagai ketua Tim peneliti Fapet UGM, yang telah memberikan kesempatan dan kepercayaan kepada Penulis dalam melakukan penelitian bersama yang dilakukan oleh Tim peneliti Fapet UGM.

\section{DAFTAR PUSTAKA}

Agus,A., Suwignyo B,. Budisatria IGS,. Maharani, D. Widi, TSMW. Triyannanto, E. Wankar, TJ. Wulandari, E. dan Ibrahim, A. (2017). Kajian Implementasi Instrumen Kebijakan Rasio Impor Sapi Indukan dan sapi Bakalan Dalam Permentan No. 49/ Permentan/Pk440/10/2016 Jo. Permentan No. 02/ Permentan/Pk440/2/2017. Fakultas Peternakan Universitas Gadjah Mada Yogyakarta.
Anggraini, W. (2003). Analisis Usaha Peternakan Sapi Potong Rakyat Berdasarkan Biaya Produksi dan Tingkat Pendapatan Peternakan Menurut Skala Usaha. Fakultas Peternakan Institut Pertanian Bogor.

Hadi,P.U.dan Ilham, N.(2000). Peluang pengembanganusaha pembibitan ternak sapi potong di Indonesia dalam rangka swasembada daging. Makalah disampaikan pada Pertemuan Teknis Penyediaan Bibit Nasional dan Revitalisasi UPT TA 2000. Jakarta, 11-12 Juli 2000. Direktorat Perbibitan, DirektoratJenderal Bina Produksi Peternakan, Jakarta

Hadi, P.U. dan Ilham, N. (2002). Problem dan prospek pengembangan usaha pembibitan sapi potong di Indonesia. Jurnal Penelitian dan Pengembangan Pertanian 21(4): 148-157.

Handayani,S. Fariyanti,A, dan Nurmalina, R. (2016). Swasembada Daging Sapi Analisis Simulasi Ramalan Swasembada daging Saoi di Indonesia. Sosiohumaniora, 18 (1): 61 - 70

Handayani, Budiraharjo, K., dan Sanyoto, G. (2011). Analisis Profitabilitas Usaha Penggemukan Sapi Potong Di Kecamatan Gunungpati Kota Semarang. Jurnal Ilmu-ilmu Pertanian, 7 (1), 1 - 9

Nono, O.H. (2011). Dampak Kelembagaan Bagi Hasil Terhadap Kinerja Usaha Penggemukan Sapi Potong di Kabupaten Kupang. Sosiohumaniora, 13(1): $28-38$

Poetri, N. A., Basith., A., dan Wijaya N.H. (2014). Analisis Kelayakan Pengembangan Usaha Peternakan Sapi Perah KUNAK. Jurnal Manajemen dan Organisasi. V(2). 122-138.

Umiyasih, U., Gunawan, D.E. Wahyono, Anggraini, Y.N. dan Mathius, I.W. (2004). Penggunaan bahan pakan lokal sebagai upaya efisiensi pada usaha perbibitan sapi potong komersial: Prosiding Seminar Nasional Teknologi Peternakan dan Veteriner, Bogor, 4-5 Agustus 2004. Pusat Penelitian dan Pengembangan Peternakan, Bogor.

Sodiq, A. dan Budiono, M. (2012). Produktivitas Sapi Potong pada Kelompok Tani Ternak di Pedesaan. Agripet, 12,(1,): 28-33

Suharto. (2004). Pengalaman pengembangan usaha sistem integrasi sapi-kelapa sawit di Riau. hlm. 57-63 Prosiding Lokakarya Nasional Sistem Integrasi Kelapa Sawit-Sapi, Bengkulu, 9-10 September 2003. Departemen Pertanian bekerja sama dengan Pemerintah Provinsi Bengkulu dan PT Agricinal.

Suryana. (2009). Pengembangan Usaha Ternak Sapi Potong Berorientasi Agribisnis dengan Pola Kemitraan. Jurnal Litbang Pertanian, 28 (1). 29-37 
Tawaf, R and Suryadi D. (2010). Response of Feedlot Business to The Beef Market Mechnism Changed in West Java Indonesia. Journal Lucrări Ştiinţifice - vol. 54, Seria Zootehnie; 87-93
Winarso, B., Sajuti, R. dan Muslim, C. (2005). Tinjauan ekonomi ternak sapi potong di Jawa Timur. Forum Penelitian Agro Ekonomi 23 (1): 61-71. 